\title{
Elderly Women in Unorganized Sector: A Study in Hisar
}

\author{
Sumit Sheoran", Sheela Sangwan and Arti Kumari \\ Department of Human Development and Family Studies, I.C. College of Home Science, \\ CCSHAU, Hisar, Haryana- 125004, India \\ *Corresponding author
}

\section{Keywords \\ Unorganized sector, Elderly women, Health status of elderly}

\section{Article Info}

Accepted:

04 February 2019

Available Online:

10 March 2019

\begin{abstract}
A B S T R A C T
An elderly or old age woman comprises the later part of life; the period of life after youth and middle age. The elderly women lived in vulnerable conditions and don't have any vocational skills in order to earn their livelihood as their whole life is spent doing household work and their physical health didn't allowed them to work. They faced vulnerability in the psychological, economical, physical and social areas. The elderly women in unorganized sector were living in susceptible conditions and they were given less importance. It was important to understand the problems faced by the elderly in unorganized sector and the conditions under which they are living. By keeping in view the above scenario, the present study was conducted with first objective i.e., to study the current scenario of elderly women working in unorganized sector in Hisar. Second objective was to understand the socio-economic background and relationship of the elderly women with their family members. To study the elderly women workers in unorganized sectors, 100 respondents were selected through the convenient sampling method. It was found that majority of the elderly had average kind of health. One-fourth of the respondents were having fairly good health status. Few of them were unaware about their health status due to the lack of knowledge regarding health. Most of the elderly stays with chief earner of the family whereas one-third of the respondents do not stay with chief earner. As far as support of family is concerned, it was reported that half of the elderly women were not supported by their son whereas one-third of elderly were found to be supported by their family. In order to become familiar with elderly women's problems it is important to study elderly women in unorganized sector so that possible steps can be taken to improve their present status.
\end{abstract}

\section{Introduction}

The phenomenon of population ageing is flattering a major apprehension for the policy makers all over the world, equally for developed and developing countries. India too is not protected to this demographic transform. The changing demographic profile has thrown numerous new challenges in the social, economic and political domains. There is an emerging require to pay greater concentration to ageing related issues and to encourage holistic policies and programmes for dealing with ageing society. According to 
Population Census 2011 there are nearly 104 million elderly persons (aged 60 years or above) in India; 53 million females and 51 million males.

The idiom unorganized sector when used in the Indian perspective is defined by National Commission for Enterprises in the Unorganized Sector, 2008, in their report on "Conditions of Work and Promotion of Livelihoods in the Unorganized Sector" asconsisting of each unincorporated private ventures owned by persons or households occupied in the sale or manufacture of goods and services controlled on a proprietary or partnership basis and with not as much than ten total workers (Raju, 1989). Amongst the characteristic attributes of this sector are effortlessness of entry, smaller level of operation, local ownership, uncertain lawful status, labor-intensive and operating using lesser technology based methods, supple pricing, less sophisticated packing, lack of a brand name, unavailability of superior storage facilities and an efficient distribution network, inadequate right to use government schemes, finance and government aid, lower access barriers for employees, a higher split of migrants with a lower pace of compensation. Employees belonging to unorganized sector have lesser job security and lower chances of growth, and no leaves and paid holidays, they have no protection against employers indulging in unfair or illegal means (Gupta, 2009).

In traditional India, elderly had been protected by strong bond of their family, kinship and community but due to adjustment of latest trend globalization which led to industrialization and urbanization had left profound impact on life of elderly. Due to these adjustments have led to changes in society in positive way but it also have consequences that is in terms of lack of appropriate housing which forces the deprived to live in slums, low income levels, high percentage of rural migrants, elevated rates of unemployment, personal and social problems there is need of access to public and basic facilities including healthcare systems. The elderly in urban areas are more prone to these changes as they come in search for improved livelihood which in rotate results into living a life in miserable way. The elderly in rural area are still supported by their families in every possible way whereas elderly in urban areas are left alone. In today world elderly have regarded as burden on their family as they do not contribute in family income and are completely dependent for their survival and mostly they are ignored by their own family members as result of which is loss of status. They are lacking of basic right of decision making which leads to substandard position in their own family.

The elderly in organized sector have some sort of security like retirement benefits or pension and they are fully aware of their rights and can fight for it. On the contrary condition of elderly in unorganized sector is vulnerable. Most of the elderly are still working just to fulfill their basic necessities and also they are also unaware of rights and schemes that are meant for their welfare. Government of India already have various schemes for the welfare of elderly but there are very few who know about these schemes and some have applied for it and do not have access to it.

Hence, it is important to understand the problems faced by the elderly in unorganized sector and the conditions under which they are living. Considering the significance of the present study was conducted with the following detailed objectives:

The first objective of the research was to study the current scenario of elderly women working in unorganized sector in Hisar. 
Second objective was to understand the socioeconomic background and relationship of the elderly women with their family members.

\section{Materials and Methods}

In order to meet the requirement of the study, 100 respondents were selected through the convenient sampling method. By using a self prepared structured interview schedule data was collected personally.

\section{Results and Discussion}

The perusal of data revealed that half of the respondents were in the age range of 60-64 years followed by the age category 65-70 years and 70 years and above. Figures pertaining to elderly women' education revealed that half of them were illiterate. Onefourth of the respondents were educated up to primary followed by secondary educated respondents. Only some of the respondents were Graduate. Regarding marital status of the elderly women, results unfold that 68 per cent of were married and 30 per cent were widowed. Data regarding family type of the respondents revealed that 65 per cent were having nuclear family type followed by joint family type i.e. 30 per cent. Some of the elderly women were staying alone.

As far as occupation is concerned 35 per cent of the respondents were belonging to homemaker category. 30 per cent were falling under daily wages category, 25 per cent were factory employee and 10 per cent were shopkeepers. Examining the total sample for working hours unfold that half of the elderly women were working for 2-6 hours followed by the aged working for 6-10 hours. There were 15 respondents, who were working more than 10 hours per day. Perusal of results further showed that most of the respondents were earning less than ₹2000/month. Monthly family income and size of family are the key factors which affects to the health and various other facilities, which the respondent receive at home.

Majority of the elderly were working in average work environment (availability of proper lightning, ventilation, building structure etc.), 35 per cent of the respondents were working under poor working conditions. Only 15 per cent of the elderly were having proper working conditions. With regard to retirement benefits/ plans of elderly, results portray that more than fifty percent of the total sample were having no retirement plans. The interpretation of the data reveals that more than half of the respondents were having their own home, 35 per cent of aged were living in rented home whereas, 13 per cent of the sample population were living the houses provided by their company/ factory owner.

It is evident from the data that majority of the respondents were living with the chief earner of the family (77 per cent) whereas, 23 per cent of the elderly were living independently. As far as family decision making is concerned half of the respondents never participated and 35 per cent of respondents participated sometime. Only 15 per cent of the elderly women always participated in the family decision making process. Examining the total sample unfold that majority of the elderly women were unsatisfied with the family members behavior whereas one- third of them were satisfied with family members behavior. Perusal of results further showed that most of the respondents were having savings/ property for their future security.

Most of the elderly have transferred their property to the chief earner of the family and 15 per cent of the respondents have donated their property to the social welfare trusts. 20 per cent of the elderly have transferred their property to their daughters and an equal per cent of elderly have transferred their property 
to no one. With regard to health status of elderly, results portray that majority of the total sample were having average health. Few of them were unaware about their health status. The data further reveals that most of the respondents were having regular prescribed medication by Doctor (45 per cent) followed by the irregular/ sometimes adaptation towards prescribed medication whereas, 16 per cent of the sample population were having no health problems. A major per cent of the elderly were having access to the health facilities whereas 38 per cent of the respondents were having no such access.

Table.1 Personal Profile of the Respondents

\begin{tabular}{|c|c|c|c|}
\hline S. No. & Variables & Particulars & $\begin{array}{c}\text { No. of Respondents }(\%) \\
(\mathrm{N}=100)\end{array}$ \\
\hline \multirow[t]{3}{*}{1.} & \multirow[t]{3}{*}{ Age } & $60-64$ years & 55 \\
\hline & & $65-70$ years & 30 \\
\hline & & 70 years and above & 15 \\
\hline \multirow[t]{4}{*}{2.} & \multirow{4}{*}{$\begin{array}{l}\text { Education of the } \\
\text { respondents }\end{array}$} & Illiterate & 55 \\
\hline & & Primary & 25 \\
\hline & & Secondary & 16 \\
\hline & & Graduate & 4 \\
\hline \multirow[t]{3}{*}{3.} & \multirow{3}{*}{$\begin{array}{l}\text { Marital status of the } \\
\text { respondents }\end{array}$} & Married & 68 \\
\hline & & Unmarried & 2 \\
\hline & & Widowed & 30 \\
\hline \multirow[t]{3}{*}{4.} & \multirow[t]{3}{*}{ Family type } & Nuclear & 65 \\
\hline & & Joint & 30 \\
\hline & & Alone & 5 \\
\hline
\end{tabular}

Table. 2 Current scenario and socio-economic profile of the elderly women working in unorganized sector in Hisar

\begin{tabular}{|c|c|c|c|}
\hline S. No. & Variables & Particulars & $\begin{array}{c}\text { No. of Respondents }(\%) \\
(\mathrm{N}=100)\end{array}$ \\
\hline \multirow[t]{4}{*}{1} & \multirow{4}{*}{ Occupation } & Home- maker & 35 \\
\hline & & Shopkeeper & 10 \\
\hline & & Factory employee & 25 \\
\hline & & Daily wages & 30 \\
\hline \multirow[t]{3}{*}{2.} & \multirow[t]{3}{*}{ Working hours (per day) } & 2-6 hours & 50 \\
\hline & & 6-10 hours & 35 \\
\hline & & More than 10 hours & 15 \\
\hline \multirow[t]{3}{*}{3.} & \multirow{3}{*}{$\begin{array}{l}\text { Monthly income of the } \\
\text { respondents (Rs.) }\end{array}$} & Less than 2000 & 65 \\
\hline & & $2000-4000$ & 30 \\
\hline & & More than 4000 & 5 \\
\hline \multirow[t]{3}{*}{4.} & \multirow[t]{3}{*}{ Type of working conditions } & Poor & 35 \\
\hline & & Average & 50 \\
\hline & & Good & 15 \\
\hline \multirow[t]{2}{*}{5.} & \multirow{2}{*}{$\begin{array}{l}\text { Any retirement benefits/plans by } \\
\text { company/factory }\end{array}$} & Yes & 35 \\
\hline & & No & 65 \\
\hline \multirow[t]{3}{*}{6.} & \multirow[t]{3}{*}{ Type of dwelling } & Own & 52 \\
\hline & & Rent & 35 \\
\hline & & Provided by company & 13 \\
\hline
\end{tabular}


Table.3 Relationship of the elderly women with their family members

\begin{tabular}{|c|c|c|c|}
\hline S. No. & Variables & Particulars & $\begin{array}{c}\text { No. of Respondents } \\
(\mathrm{N}=100)\end{array}$ \\
\hline \multirow[t]{2}{*}{1} & \multirow{2}{*}{$\begin{array}{l}\text { Living with the chief earner of } \\
\text { the family }\end{array}$} & Yes & 77 \\
\hline & & No & 23 \\
\hline \multirow[t]{3}{*}{2.} & \multirow{3}{*}{$\begin{array}{l}\text { Family decision making } \\
\text { respondent's participation }\end{array}$} & Never & 50 \\
\hline & & Sometimes & 35 \\
\hline & & Always & 15 \\
\hline \multirow[t]{2}{*}{3.} & \multirow{2}{*}{ Behavior of family members } & Satisfactory & 25 \\
\hline & & Unsatisfactory & 75 \\
\hline \multirow[t]{2}{*}{4.} & \multirow{2}{*}{$\begin{array}{l}\text { Savings/ property by the } \\
\text { respondent }\end{array}$} & Yes & 86 \\
\hline & & No & 14 \\
\hline \multirow[t]{4}{*}{5.} & \multirow{4}{*}{ Transfer of property } & Chief Family Earner & 45 \\
\hline & & Daughter & 20 \\
\hline & & $\begin{array}{c}\text { Any Social Welfare } \\
\text { Trust }\end{array}$ & 15 \\
\hline & & No one & 20 \\
\hline \multirow[t]{3}{*}{6.} & \multirow[t]{3}{*}{ Health Status } & Fairly Good & 18 \\
\hline & & Average & 70 \\
\hline & & Do not know & 12 \\
\hline \multirow[t]{3}{*}{7.} & \multirow{3}{*}{$\begin{array}{l}\text { Using prescribed medication by } \\
\text { Doctor }\end{array}$} & Regular & 45 \\
\hline & & Sometimes & 39 \\
\hline & & Never & 16 \\
\hline \multirow[t]{2}{*}{8.} & \multirow{2}{*}{$\begin{array}{l}\text { Access to the prescribed } \\
\text { medication by Doctor }\end{array}$} & Yes & 62 \\
\hline & & No & 38 \\
\hline
\end{tabular}

In conclusion, women excel in all fields whether it is work place or home. They play their roles as a daughter, wife, and mother along with that they play a vital role in economic development of the country and their contribution is nothing short of their male counterparts. However there are several issues and problems that women face today. Sometimes, they are not treated equally in their place of work and are considered as substandard to their male co-workers. In some cases they do not get the equal benefits as that of a male employee. The major issues and problems that women face in their work places include unequal pay scale, insecurity, sexual harassment, etc. The problems get multiplied when working women' families do not support them, for whom she works. As far as support of family is concerned, it was reported that half of the elderly women were not supported by their families whereas onethird of elderly were found to be supported by their family. It was found that majority of the elderly had average kind of health. One-fourth of the respondents were having fairly good health status. Few of them were unaware about their health status due to the lack of knowledge regarding health. A large number of elderly were on regular medication. Majority of them were having access to health facilities. Most of the elderly stays with chief earner of the family whereas one-third of the respondents do not stay with chief earner. Majority of elderly women were illiterate and belonging to the nuclear families. Major part of the aged women were home-makers and 
working on daily wages. Most of them were working for 2-6 hours per day under average conditions but still they were earning less than Rs. 2000/ month. They were getting no retirement benefits from their workplace. Only half of them were having their own home and most of them have transferred their property to the chief earner of the family.

\section{Suggestions}

Interventions must be provided elderly women in order to empower them

Training health care professionals in geriatric concern

Affordable, reachable and available health and home services

Ensuring food and nutrition security of poor elderly through subsidized rations and midday meals

Provision of Mobile Medicare Units in remote areas

Setting up Multi Service Resource centers' - counseling, skill development, holistic health care

To ensure income security by enhancement and suitable disbursement of the existing social pensions (old age pension and widow pension).

Quality research in gerontology

Organizing women into groups / SHGs

\section{References}

Gupta K., R., (2009). Economics of Development and Planning. Atlantic Publishers and Dist. pp. 746. Retrieved 26 March 2013.

Raju, R., S., (1989). Urban Unorganised Sector in India. Mittal Publications. pp. 11-17.

Report On Conditions Of Work and Promotion Of Livelihoods In The Unorganized Sector (2008). Academic Foundation. Pp. 1774. Retrieved 26 March 2013.

\section{How to cite this article:}

Sumit Sheoran, Sheela Sangwan and Arti Kumari. 2019. Elderly Women in Unorganized Sector: A Study in Hisar. Int.J.Curr.Microbiol.App.Sci. 8(03): 68-73. doi: https://doi.org/10.20546/ijcmas.2019.803.010 